\title{
SISTEM PENDUKUNG KEPUTUSAN PENENTUAN TANAMAN OBAT SESUAI JENIS PENYAKIT MENGGUNAKAN METODE TOPSIS
}

\author{
Haryo Vendy Brahmantyo ${ }^{1}$, Rudy Ariyanto \\ Program Studi Teknik Informatika, Jurusan Teknologi Informasi, Politeknik Negeri Malang \\ 1.haryovendy,brahmantyo@gmail.com, 2ªriyantorudy@gmail.com
}

\begin{abstract}
Abstrak
Tanaman Obat adalah tanaman yang sengaja ditanam maupun tumbuh secara liar namun memiliki kandungan zat tertentu yang dapat menyembuhkan suatu jenis penyakit seperti diabetes, hipertensi, kolesterol. Tanaman Obat ini banyak dibudidayakan oleh masyarakat dan intansi pemerintah salah satunya UPT.Materia Medica Batu. karena begitu banyaknya jenis tanaman obat, seringkali membuat masyarakat merasa kesulitan dalam menentukan tanaman obat yang sesuai kebutuhan jika ditinjau dari sisi harga yang terjangkau, rasa dari tanaman tersebut, kemudahan dalam mendapatkan tanaman dan kandungan yang dimiliki oleh tanaman obat tersebut. Oleh karena ini penelitian ini mengusulkan sebuah sistem pendukung keputusan untuk penentuan tanaman obat sesuai jenis penyakit untuk menghasilkan urutan alternatif tanaman obat terbaik menggunakan metode TOPSIS. Berdasarkan pengujian, sistem ini dapat mengimplementasikan perhitungan menggunakan metode TOPSIS dengan tingkat akurasi $100 \%$ untuk masing-masing jenis penyakit yang diuji.
\end{abstract}

Kata kunci : sistem pendukung keputusan, tanaman obat, TOPSIS.

\section{Pendahuluan}

Tanaman obat-obatan tradisional adalah tanaman yang dapat dipergunakan sebagai obat, baik yang sengaja ditanam maupun tumbuh secara liar. Tanaman tersebut dimanfaatkan oleh masyarakat untuk diramu dan disajikan sebagai obat guna penyembuhan penyakit. Menurut Trinita (2010:1) mengatakan bahwa data dari Departemen Kesehatan Republik Indonesia terdapat sekitar 1.000 jenis tanaman yang dinyatakan memiliki kandungan untuk dimanfaatkan sebagai tanaman obat dimana sekitar 350 spesies telah banyak digunakan oleh masyarakat maupun industri sebagai bahan baku obat-obatan dan banyak dibudidayakan di Indonesia.

Tanaman obat juga dapat menyembuhkan berbagai macam penyakit seperti Hipertensi, Kolesterol,dan Diabetes yang merupakan jenis penyakit metabolis syndrome. Namun dengan banyaknya jenis tanaman obat tersebut, seringkali membuat masyarakat merasa kesulitan dalam memilih tanaman obat yang sesuai kebutuhan jika ditinjau dari sisi harga yang terjangkau, rasa dari tanaman tersebut, kemudahan dalam mendapatkan tanaman obat dan kandungan yang berkhasiat untuk mengatasi suatu jenis penyakit. Kebanyakan masyarakat memanfaatkan tanaman obat menggunakan metode pemilihan secara turun temurun berdasarkan pengalaman maupun pengetahuan tradisional.

Dalam kasus ini, terdapat beberapa unsur kriteria yang setiap kriteria memiliki range nilai yang berbeda. Maka dari itu, aplikasi sistem pendukung keputusan ini diperlukan suatu metode The Technique for Order of Preference by Similarity to Ideal Solution (TOPSIS) yang kriterianya merupakan faktor penilaian untuk dapat memberikan peringkat alternatif tanaman obat yang terbaik. Sehingga, penentuan tanaman obat dengan menggunakan metode TOPSIS diharapkan tanaman obat yang direkomendasikan benar-benar sesuai dengan keinginan, kebutuhan, dan kemampuan konsumen.

\section{Tinjauan Pustaka}

\subsection{Sistem Pendukung Keputusan}

SPK adalah sistem informasi berbasis komputer interaktif dengan koleksi terorganisir dari model, orang, prosedur, software, database, telekomunikasi, dan perangkat, yang membantu para pengambil keputusan untuk memecahkan terstruktur atau semiterstruktur masalah bisnis (Tripathi, 2011)

\subsection{Tanaman Obat}

Tanaman obat-obatan tradisional adalah tanaman yang dapat dipergunakan sebagai obat, baik yang sengaja ditanam maupun tumbuh secara liar. Tanaman tersebut dimanfaatkan oleh masyarakat untuk diramu dan disajikan sebagai obat guna penyembuhan penyakit. Sekitar 9.600 spesies diketahui berkhasiat obat, tetapi baru 200 spesies saja yang telah dimanfaatkan sebagai bahan baku pada 
industri obat tradisional. Peluang pengembangan budidaya tanaman obat-obatan masih sangat terbuka luas, sejalan dengan semakin berkembangnya industri jamu, obat herbal dan kosmetika tradisional (Prasetyono, 2012 :707-710)

\subsection{TOPSIS}

TOPSIS adalah salah satu metode pengambilan keputusan multikriteria yang pertama kali diperkenalkan oleh Yoon dan Hwang pada tahun 1981. TOPSIS menggunakan prinsip bahwa alternatif yang terpilih harus mempunyai jarak terdekat dari solusi ideal positif dan terjauh dari solusi ideal negatif Adapun langkah-langkah algoritma dari TOPSIS ini adalah sebagai berikut (Indira, 2012) :

a. Rangking Tiap Alternatif

TOPSIS membutuhkan ranking kinerja setiap alternatif $\mathrm{Ai}$ pada setiap kriteria $\mathrm{Cj}$ yang ternormalisasi yaitu :

$$
r_{i j}=\frac{x_{i j}}{\sqrt{\sum_{i-1}^{m} x_{i j}^{2}}}
$$

dengan $i=1,2, \ldots . m$; dan $j=1,2, \ldots \ldots$.

b. Matriks keputusan ternormalisasi terbobot

$$
y_{i j}=w_{i} r_{i j}
$$

Dengan $\mathrm{i}=1,2, \ldots, \mathrm{m} ;$ dan $\mathrm{j}=1,2, \ldots, \mathrm{n}$

c. Solusi Ideal Positif Dan Negatif

Solusi ideal positif A+ dan solusi ideal negatif Adapat ditentukan berdasarkan ranking bobot ternormalisasi (yij) sebagai berikut :

$A^{+}=\left(y_{1}^{+}, y_{2}^{+}, \ldots, y_{n}^{+}\right)$.
$A^{-}=\left(y_{1}^{-}, y_{2}^{-}, \ldots, y_{n}^{-}\right)$

$A^{-}=\left(y_{1}, y_{2}, \ldots, y_{n}\right)$

dengan

$$
y_{j}^{+}=
$$

$\max _{i} j_{i j} ; j i k a j$ adalah atribut keuntungan

$\min _{i} j_{i j} ; j i k a j$ adalah atribut biaya

$$
y_{j}^{-}=
$$

$\min _{i} j_{i j} ; j i k a j$ adalah atribut keuntungan

$\left\{\max _{i} j_{i j} ; j i k a j\right.$ adalah atribut biaya

$$
\mathrm{j}=1,2, \ldots, \mathrm{n}
$$

d. Jarak Dengan Solusi Ideal

Jarak antara alternatif $A_{i}$ dengan solusi ideal positif dirumuskan sebagai:

$$
D_{i}^{+}=\sqrt{\sum_{j=1}^{n}\left(y_{i}^{+}-y_{i j}\right)^{2}} \text {. }
$$

Dengan $\mathrm{i}=1,2, \ldots, \mathrm{m}$

Jarak antara alternatif $A_{i}$ dengan solusi ideal negatif dirumuskan sebagai:

$$
\begin{gathered}
D_{i}^{-}= \\
\sqrt{\sum_{j=1}^{n}\left(y_{i j}-y_{i}^{-}\right)^{2}} \ldots \ldots \ldots \\
\text { dengan } \mathrm{i}=1,2, \ldots, \mathrm{m}
\end{gathered}
$$

e. Nilai Preferensi Untuk Setiap Alternatif

Nilai preferensi untuk setiap alternatif (Vi) diberikan sebagai :

$$
V_{i}=\frac{D_{i}^{-}}{D_{i}^{-}+D_{i}^{+}}
$$

Dengan $\mathrm{i}=1,2, \ldots, \mathrm{m}$

Nilai Vi yang lebih besar menunjukkan bahwa alternatif Ai lebih dipilih.

\section{Analisa dan Perancangan}

\subsection{Gambaran Sistem}

Gambaran sistem yang akan terjadi pada Sistem Pendukung Keputusan Untuk Penentuan Tanaman Obat Menggunakan Metode TOPSIS ditunjukkan pada Gambar 1

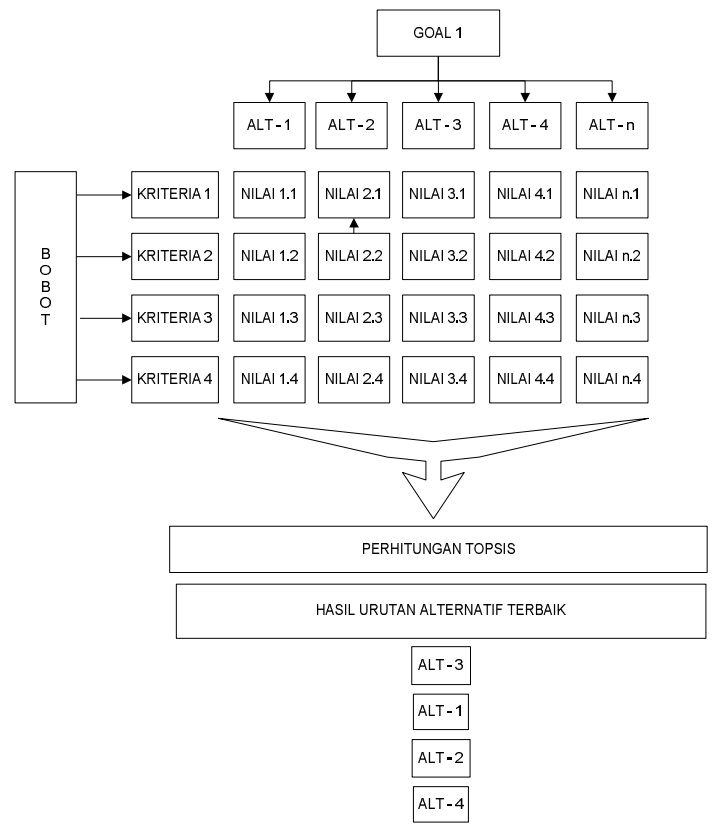

Gambar 1. Gambaran Sistem SPK Tanaman Obat

\subsection{Data Alternatif Tanaman Obat}

Data yang diuji adalah 30 sampel yang setiap tanaman obat memiliki khasiat masing-masing dalam menyembuhkan suatu jenis penyakit.

Data Tanaman Obat yang diberikan melalui proses wawancara pada UPT. Materia Medica terhadap jenis penyakit Diabetes dapat dilihat pada Tabel 1.

Tabel 1. Data Tanaman Obat dari Materia Medica terhadap penyakit Diabetes

\begin{tabular}{|c|c|c|c|}
\hline No. & Nama & No. & Nama \\
\hline 1 & Biji Mahoni & 6 & Jambu Biji \\
\hline 2 & Bunga Rosela & 7 & Keji Beling \\
\hline 3 & Daun Besaran & 8 & Kumis Kucing \\
\hline 4 & Daun Kaca Piring & 9 & Kunyit \\
\hline 5 & Daun Teh & 10 & Tapak Doro \\
\hline
\end{tabular}


Sedangkan data tanaman obat terhadap jenis penyakit Hipertensi dapat dilihat pada Tabel 2.

Tabel 2. Data Tanaman Obat dari Materia Medica terhadap penyakit Hipertensi

\begin{tabular}{|c|c|c|c|}
\hline No. & Nama & No. & Nama \\
\hline 1 & Biji Bungur & 6 & Kumis Kucing \\
\hline 2 & Bunga Rosela & 7 & Saga Manis \\
\hline 3 & Blimbing Wuluh & 8 & Sambung Legi \\
\hline 4 & Daun Besaran & 9 & Srigading \\
\hline 5 & Daun Seledri & 10 & Tapak Doro \\
\hline
\end{tabular}

Dan data tanaman obat terhadap jenis penyakit Kolesterol dapat dilihat pada Tabel 3.

Tabel 3. Data Tanaman Obat dari Materia Medica terhadap penyakit Kolesterol

\begin{tabular}{|c|c|c|c|}
\hline No. & Nama & No. & Nama \\
\hline 1 & Biji Mahoni & 6 & $\begin{array}{c}\text { Daun Kaca } \\
\text { Piring }\end{array}$ \\
\hline 2 & Buah Mengkudu & 7 & Jati Belanda \\
\hline 3 & Buah Naga & 8 & Keji Beling \\
\hline 4 & Daun Besaran & 9 & Saga Manis \\
\hline 5 & Daun Seledri & 10 & Sambung Legi \\
\hline
\end{tabular}

\subsection{Data Kriteria dan Rating Penilaian}

Terdapat empat kriteria antara lain sebagai berikut :

a. Harga = Semakin murah harga dari tanaman obat tersebut, maka nilai yang diberikan semakin tinggi.

b. Rasa $=$ Semakin manis rasa dari tanaman obat tersebut, maka nilai yang diberikan semakin tinggi.

c. Penyediaan Bahan = Semakin mudahnya tanaman obat didapatkan, maka nilai yang diberikan juga semakin tinggi.

d. Zat berkhasiat. $=$ Semakin banyak zat yang terkandung maka semakin baik juga tanaman obat tersebut dapat menyembuhkan banyak jenis penyakit

Berdasarkan kriteria tersebut diberikan rating kecocokan setiap alternatif pada setiap kriteria berupa skala yang ditunjukkan pada Tabel 4

Tabel 4. Rating Kecocokan Antar Kriteria

\begin{tabular}{|c|c|c|}
\hline Kriteria & Keterangan & Nilai \\
\hline \multirow{4}{*}{ Harga (K1) } & Sangat Mahal & 1 \\
\cline { 2 - 3 } & Mahal & 3 \\
\cline { 2 - 3 } & Murah & 5 \\
\cline { 2 - 3 } & Sangat Murah & 7 \\
\hline \multirow{4}{*}{ Rasa (K2) } & Pahit & 1 \\
\cline { 2 - 3 } & Pedas & 3 \\
\cline { 2 - 3 } & Tidak Berasa & 5 \\
\cline { 2 - 3 } Penyediaan Bahan & Manis & 7 \\
\hline \multirow{4}{*}{ K3) } & Sulit & 1 \\
\cline { 2 - 3 } & Cukup Sulit & 3 \\
\cline { 2 - 3 } & Mudah & 5 \\
\cline { 2 - 3 } & Sangat Mudah & 7 \\
\hline \multirow{4}{*}{ Zat Berkhasiat (K4) } & Sedikit & 1 \\
\cline { 2 - 3 } & Cukup & 3 \\
\cline { 2 - 3 } & Banyak & 5 \\
\cline { 2 - 3 } & Sangat Banyak & 7 \\
\hline
\end{tabular}

\section{Implementasi}

\subsection{Implementasi Basis Data}

Basis data yang diperlukan dalam sistem ini diberi nama 'spk_tanobat' seperti Gambar 2.

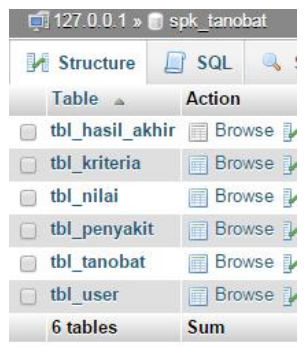

Gambar 2. Implementasi Basis Data

\subsection{Implementasi Antarmuka}

Perancangan yang telah dibuat, akan diimplementasikan kedalam aplikasi sistemp pendukung keputusan. Halaman pilih tanaman obat adalah proses memilih alternatif tanaman obat yang akan dihitung sesuai jenis penyakit yang dipilih sebelumnya, dapat ditunjukkan pada Gambar 3.

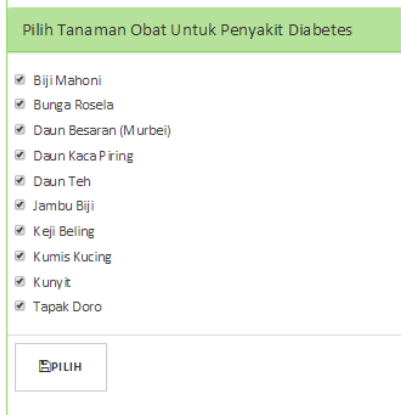

Gambar 3. Halaman Pilih Tanaman Obat

Sedangkan halaman penilaian alternatif adalah halaman dimana penilai memberikan nilai pada alternatif yang telah dipilih sebelumnya dan dapat ditunjukkan pada Gambar 4.

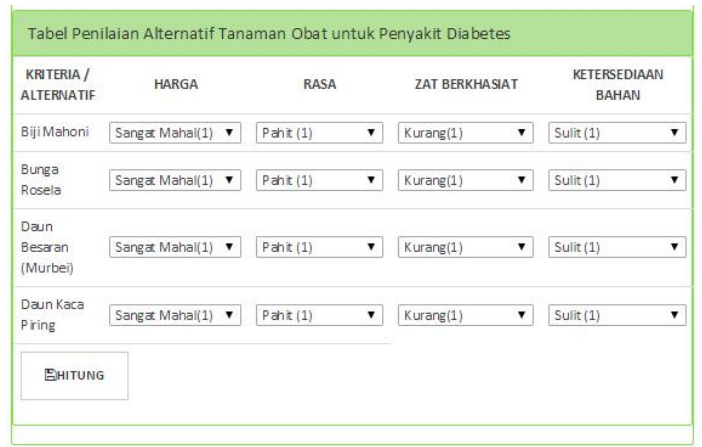

Gambar 4. Halaman Penilaian Alternatif

Halaman hasil urutan alternatif menampilkan hasil perhitungan dengan menggunakan metode TOPSIS 
berdasarkan nilai yang diberikan dan dapat dilihat pada Gambar 5.

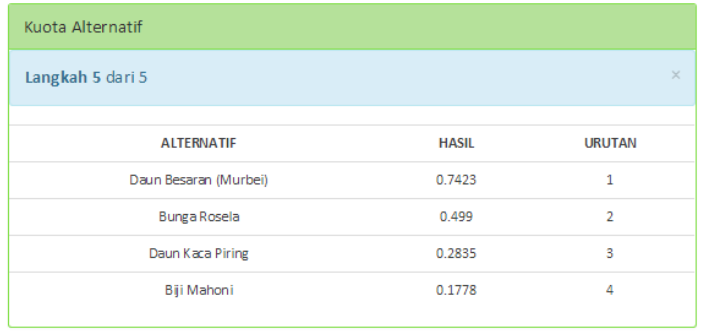

Gambar 5. Halaman Hasil Penilaian Alternatif

\section{Uji Coba dan Pembahasan}

\subsection{Uji Coba}

5.1.1 Uji Coba Perhitungan

A. Menentukan Matriks Penilaian Alternatif

Nilai dari data tanaman obat membentuk matriks penilaian alternatif penyakit diabetes ditunjukkan pada Tabel 5.

Tabel 5. Penilaian Alternatif Penyakit Diabetes

\begin{tabular}{|c|c|c|c|c|c|}
\hline & \multicolumn{2}{|c|}{ K1 } & K2 & K3 & K4 \\
\hline Biji Mahoni & 1 & & 1 & 5 & 3 \\
\hline Bunga Rosela & 7 & & 7 & 5 & 3 \\
\hline Jambu Biji & 7 & & 7 & 5 & 1 \\
\hline Kunyit & 7 & & 5 & 7 & 5 \\
\hline \multicolumn{6}{|c|}{$\begin{array}{l}\text { Sedangkan untuk penyakit hipertens } \\
\text { ditunjukkan pada Tabel } 6 \text {. } \\
\text { Tabel 6. Penilaian Alternatif Penyakit Hipertensi }\end{array}$} \\
\hline & & K1 & $\mathrm{K} 2$ & K3 & K4 \\
\hline Biji Bungur & & 3 & 1 & 3 & 3 \\
\hline Bunga Srigadin & & 1 & 1 & 3 & 3 \\
\hline Daun Seledri & & 7 & 5 & 7 & 1 \\
\hline Saga Manus & & 5 & 7 & 3 & 5 \\
\hline
\end{tabular}

Dan untuk penyakit kolesterol ditunjukkan pada Tabel 7.

Tabel 7. Penilaian Alternatif Penyakit Kolesterol

\begin{tabular}{|c|c|c|c|c|}
\hline & K1 & K2 & K3 & K4 \\
\hline Buah Naga & 7 & 7 & 5 & 1 \\
\hline Daun Besaran & 7 & 5 & 5 & 7 \\
\hline Jati Belanda & 3 & 1 & 5 & 5 \\
\hline Sambung Legi & 3 & 3 & 3 & 7 \\
\hline
\end{tabular}

B. Menentukan matriks keputusan ternormalisasi (ranking antar alternatif)

Dengan menggunakan persamaan (1) maka matriks keputusan ternormalisasi penyakit diabetes ditunjukkan pada Tabel 8.

Tabel 8. Matriks Ternormalisasi Penyakit Diabetes

\begin{tabular}{|c|c|c|c|c|}
\hline & K1 & K2 & K3 & K4 \\
\hline Biji Mahoni & 0.0822 & 0.0898 & 0.4490 & 0.4523 \\
\hline Bunga Rosela & 0.5754 & 0.6286 & 0.4490 & 0.4523 \\
\hline Jambu Biji & 0.5754 & 0.6286 & 0.4490 & 0.1508 \\
\hline Kunyit & 0.5754 & 0.4490 & 0.6286 & 0.7538 \\
\hline
\end{tabular}

Sedangkan untuk penyakit hipertensi ditunjukkan pada Tabel 9.

Tabel 9. Matriks Ternormalisasi Penyakit Hipertensi

\begin{tabular}{|c|c|c|c|c|}
\hline & K1 & K2 & K3 & K4 \\
\hline Biji Bungur & 0.3273 & 0.1147 & 0.3441 & 0.4523 \\
\hline $\begin{array}{c}\text { Bunga } \\
\text { Srigading }\end{array}$ & 0.1091 & 0.1147 & 0.3441 & 0.4523 \\
\hline Daun Seledri & 0.7638 & 0.5735 & 0.8030 & 0.1508 \\
\hline Saga Manus & 0.5455 & 0.8030 & 0.3441 & 0.7538 \\
\hline
\end{tabular}

Dan untuk penyakit kolesterol dapat dilihat pada Tabel 10

Tabel 10. Matriks Ternormalisasi Penyakit Kolesterol

\begin{tabular}{|c|c|c|c|c|}
\hline & K1 & K2 & K3 & K4 \\
\hline Buah Naga & 0.6499 & 0.7638 & 0.5455 & 0.0898 \\
\hline Daun Besaran & 0.6499 & 0.5455 & 0.5455 & 0.6286 \\
\hline Jati Belanda & 0.2785 & 0.1091 & 0.5455 & 0.4490 \\
\hline Sambung Legi & 0.2785 & 0.3273 & 0.3273 & 0.6286 \\
\hline
\end{tabular}

C. Menentukan matriks keputusan ternormalisasi terbobot

Dengan menggunakan persamaan (2) maka matriks keputusan ternormalisasi terbobot penyakit diabetes ditunjukkan pada Tabel 11 .

Tabel 11. Matriks Ternormalisasi Terbobot Penyakit Diabetes

\begin{tabular}{|c|c|c|c|c|}
\hline & K1 & K2 & K3 & K4 \\
\hline Biji Mahoni & 0.0247 & 0.0090 & 0.0898 & 0.1809 \\
\hline Bunga Rosela & 0.1726 & 0.0629 & 0.0898 & 0.1809 \\
\hline Jambu Biji & 0.1726 & 0.0629 & 0.0898 & 0.0603 \\
\hline Kunyit & 0.1726 & 0.0449 & 0.1257 & 0.3015 \\
\hline
\end{tabular}

Sedangkan untuk penyakit hipertensi ditunjukkan pada Tabel 12.

Tabel 12. Matriks Ternormalisasi Terbobot Penyakit Hipertensi

\begin{tabular}{|c|c|c|c|c|}
\hline & K1 & K2 & K3 & K4 \\
\hline Biji Bungur & 0.0982 & 0.0115 & 0.0688 & 0.1809 \\
\hline $\begin{array}{c}\text { Bunga } \\
\text { Srigading }\end{array}$ & 0.0327 & 0.0115 & 0.0688 & 0.1809 \\
\hline Daun Seledri & 0.2291 & 0.0574 & 0.1606 & 0.0603 \\
\hline Saga Manus & 0.1637 & 0.0803 & 0.0688 & 0.3015 \\
\hline
\end{tabular}

Dan untuk penyakit kolesterol dapat dilihat pada Tabel 13

Tabel 13. Matriks Ternormalisasi Terbobot Penyakit Kolesterol

\begin{tabular}{|c|c|c|c|c|}
\hline & K1 & K2 & K3 & K4 \\
\hline Buah Naga & 0.1950 & 0.0764 & 0.1091 & 0.0359 \\
\hline Daun Besaran & 0.1950 & 0.0546 & 0.1091 & 0.2514 \\
\hline Jati Belanda & 0.0836 & 0.0109 & 0.1091 & 0.1796 \\
\hline Sambung Legi & 0.0836 & 0.0327 & 0.0655 & 0.2514 \\
\hline
\end{tabular}

D. Menentukan nilai solusi ideal positif dan solusi ideal negatif

Dengan menggunakan persamaan (3) dan persamaan (4) maka didapatkan solusi ideal 
positif dan negatif dari penyakit diabetes ditunjukkan pada Tabel 14.

Tabel 14. Nilai Solusi Ideal Positif dan Solusi Ideal Negatif Penyakit Diabetes

\begin{tabular}{|c|c|c|c|c|}
\hline & K1 & K2 & K3 & K4 \\
\hline$A^{+}$ & 0.1726 & 0.0629 & 0.1257 & 0.3015 \\
\hline$A^{-}$ & 0.0247 & 0.0090 & 0.0898 & 0.0603 \\
\hline
\end{tabular}

Sedangkan untuk penyakit hipertensi ditunjukkan pada Tabel 15.

Tabel 15. Nilai Solusi Ideal Positif dan Solusi Ideal Negatif Penyakit Hipertensi

\begin{tabular}{|c|c|c|c|c|}
\hline & K1 & K2 & K3 & K4 \\
\hline$A^{+}$ & 0.2291 & 0.0803 & 0.1606 & 0.3015 \\
\hline$A^{-}$ & 0.0327 & 0.0115 & 0.0688 & 0.0603 \\
\hline
\end{tabular}

Dan untuk penyakit kolesterol dapat dilihat pada Tabel 16.

Tabel 16. Nilai Solusi Ideal Positif dan Solusi Ideal Negatif Penyakit Kolesterol

\begin{tabular}{|c|c|c|c|c|}
\hline & K1 & K2 & K3 & K4 \\
\hline$A^{+}$ & 0.1950 & 0.0764 & 0.1091 & 0.2514 \\
\hline$A^{-}$ & 0.0836 & 0.0109 & 0.0655 & 0.0359 \\
\hline
\end{tabular}

E. Menentukan jarak antar nilai alternatif dengan solusi ideal positif dan solusi ideal negatif

Dengan menggunakan persamaan (5) dan persamaan (6) maka jarak antar nilai alternatif dengan solusi ideal positif dan negatif dari penyakit diabetes ditunjukkan pada Tabel 17.

Tabel 17. Jarak Antar Nilai Alternatif dengan Solusi Ideal Positif dan Negatif Penyakit Diabetes

\begin{tabular}{|c|c|c|}
\hline & $\boldsymbol{D}^{+}$ & $\boldsymbol{D}^{-}$ \\
\hline Biji Mahoni & 0.2016 & 0.1206 \\
\hline Bunga Rosela & 0.1258 & 0.1983 \\
\hline Jambu Biji & 0.2439 & 0.1575 \\
\hline Kunyit & 0.0180 & 0.2875 \\
\hline
\end{tabular}

Sedangkan untuk penyakit hipertensi ditunjukkan pada Tabel 18 .

Tabel 18 Jarak Antar Nilai Alternatif dengan Solusi Ideal Positif dan Negatif Penyakit Hipertensi

\begin{tabular}{|c|c|c|}
\hline & $\boldsymbol{D}^{+}$ & $\boldsymbol{D}^{-}$ \\
\hline Biji Bungur & 0.2118 & 0.1372 \\
\hline Bunga Srigading & 0.2574 & 0.1206 \\
\hline Daun Seledri & 0.2423 & 0.2216 \\
\hline Saga Manus & 0.1127 & 0.2830 \\
\hline
\end{tabular}

Dan untuk penyakit kolesterol dapat dilihat pada Tabel 19.

Tabel 19. Jarak Antar Nilai Alternatif dengan Solusi Ideal Positif dan Negatif Penyakit Kolesterol

\begin{tabular}{|c|c|c|}
\hline & $\boldsymbol{D}^{+}$ & $\boldsymbol{D}^{-}$ \\
\hline Buah Naga & 0.2155 & 0.1364 \\
\hline Daun Besaran & 0.0218 & 0.2503 \\
\hline Jati Belanda & 0.1479 & 0.1502 \\
\hline Sambung Legi & 0.1274 & 0.2166 \\
\hline
\end{tabular}

F. Menentukan nilai preferensi untuk setiap alternatif

Dengan menggunakan persamaan (7) didapatkan nilai preferensi untuk setiap alternatif dari penyakit diabetes ditunjukkan pada Tabel 20.

Tabel 20. Nilai Preferensi Penyakit Diabetes

\begin{tabular}{|c|c|}
\hline & $\boldsymbol{V}$ \\
\hline Biji Mahoni & 0.3743 \\
\hline Bunga Rosela & 0.6118 \\
\hline Jambu Biji & 0.3924 \\
\hline Kunyit & 0.9412 \\
\hline
\end{tabular}

Sedangkan untuk penyakit hipertensi ditunjukkan pada Tabel 21.

Tabel 21. Nilai Preferensi Penyakit Hipertensi

\begin{tabular}{|c|c|}
\hline & $\boldsymbol{V}$ \\
\hline Biji Bungur & 0.3932 \\
\hline Bunga Srigading & 0.3190 \\
\hline Daun Seledri & 0.4777 \\
\hline Saga Manus & 0.7151 \\
\hline
\end{tabular}

Dan untuk penyakit kolesterol dapat dilihat pada Tabel 22.

Tabel 22. Nilai Preferensi Penyakit Kolesterol

\begin{tabular}{|c|c|}
\hline & $\boldsymbol{V}$ \\
\hline Buah Naga & 0.3876 \\
\hline Daun Besaran & 0.9198 \\
\hline Jati Belanda & 0.5039 \\
\hline Sambung Legi & 0.6297 \\
\hline
\end{tabular}

\subsubsection{Uji Coba Hasil}

Uji coba hasil terhadap empat kriteria dengan membandingkan hasil perhitungan manual dan hasil perhitungan menggunakan SPK. Untuk penyakit diabetes ditunjukkan pada Tabel 23.

Tabel 23 Perbandingan Hasil Uji Coba Penyakit Diabetes

\begin{tabular}{|c|c|c|}
\hline & $\begin{array}{c}\text { Perhitungan } \\
\text { Manual }\end{array}$ & $\begin{array}{c}\text { Perhitungan } \\
\text { Sistem SPK }\end{array}$ \\
\hline Biji Mahoni & 0.3743 & 0.3743 \\
\hline Bunga Rosela & 0.6118 & 0.6118 \\
\hline Jambu Biji & 0.3924 & 0.3924 \\
\hline Kunyit & 0.9412 & 0.9412 \\
\hline
\end{tabular}

Sedangkan untuk penyakit hipertensi akan ditunjukkan dengan Tabel 24.

Tabel 24 Perbandingan Hasil Uji Coba Penyakit Hipertensi

\begin{tabular}{|c|c|c|}
\hline & $\begin{array}{c}\text { Perhitungan } \\
\text { Manual }\end{array}$ & $\begin{array}{c}\text { Perhitungan } \\
\text { Sistem SPK }\end{array}$ \\
\hline Biji Bungur & 0.3932 & 0.3932 \\
\hline $\begin{array}{c}\text { Bunga } \\
\text { Srigading }\end{array}$ & 0.3190 & 0.3190 \\
\hline Daun Seledri & 0.4777 & 0.4777 \\
\hline Saga Manus & 0.7151 & 0.7151 \\
\hline
\end{tabular}

Dan untuk penyakit kolesterol ditunjukkan pada Tabel 25. 
Tabel 25 Perbandingan Hasil Uji Coba Penyakit Kolesterol

\begin{tabular}{|c|c|c|}
\hline & $\begin{array}{c}\text { Perhitungan } \\
\text { Manual }\end{array}$ & $\begin{array}{c}\text { Perhitungan } \\
\text { Sistem SPK }\end{array}$ \\
\hline Buah Naga & 0.3876 & 0.3876 \\
\hline Daun Besaran & 0.9198 & 0.9198 \\
\hline Jati Belanda & 0.5039 & 0.5039 \\
\hline Sambung Legi & 0.6297 & 0.6297 \\
\hline
\end{tabular}

\subsection{Pembahasan}

Setelah dilakukan uji coba perhitungan dan dilakukan perbandingan hasil maka hasil kinerja SPK tersebut mendapatkan nilai akurasi $100 \%$ untuk penyakit diabetes yang ditunjukkan pada Gambar 6, nilai akurasi $100 \%$ untuk penyakit hipertensi yang ditunjukkan pada Gambar 7 dan nilai akurasi 100\% yang ditunjukkan pada Gambar 8.

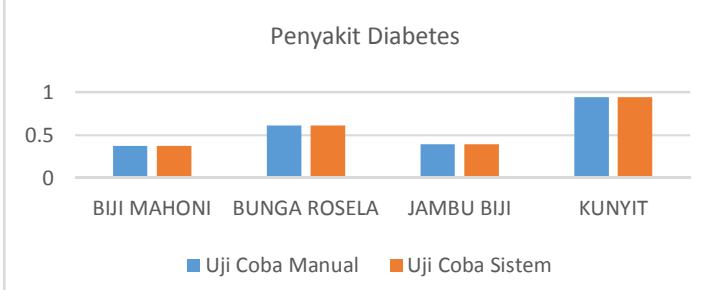

Gambar 6. Hasil Akurasi Penyakit Diabetes

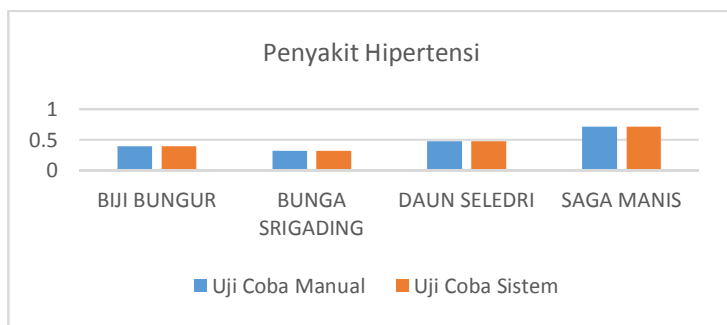

Gambar 7. Hasil Akurasi Penyakit Hipertensi

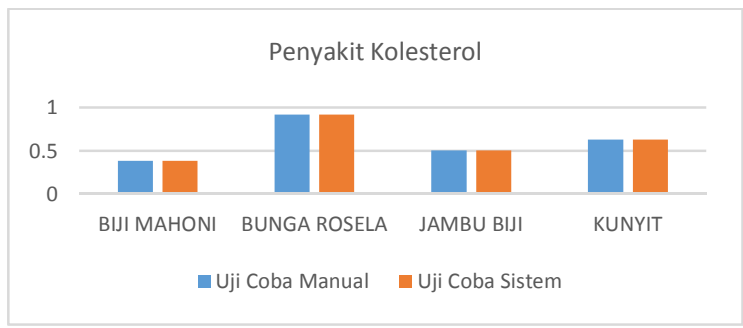

Gambar 8. Hasil Akurasi Penyakit Kolesterol

\section{Kesimpulan dan Saran}

\subsection{Kesimpulan}

Berdasarkan penelitian yang dilaksanakan oleh penulis pada pengembangan sistem pendukung keputusan untuk penentuan tanaman obat sesuai jenis penyakit menggunakan metode TOPSIS, dapat ditarik kesimpulan sebagai berikut :

- SPK menggunakan metode TOPSIS telah dibuat sesuai dengan perancangan dan dapat digunakan dalam merekomendasikan tanaman obat untuk mengambil keputusan terhadap jenis penyakit.
- SPK untuk penentuan tanaman obat berdasarkan uji coba hasil yang telah dilakukan uji coba perhitungan manual dan uji coba perhitungan dengan sistem memberikan nilai akurasi sebesar $100 \%$ untuk jenis penyakit diabetes, nilai akurasi sebesar $100 \%$ untuk jenis penyakit hipertensi dan nilai akurasi sebesar $100 \%$ untuk jenis penyakit. Dapat ditarik kesimpulan bahwa implementasi dalam penentuan tanaman obat pada sistem ini sudah sesuai.

\subsection{Saran}

Saran yang diberikan untuk pengembangan peneilitian lebih lanjut yaitu untuk memperbaiki kelemahan dalam penelitian ini maka dapat dilakukan perbaikan dalam menentukan bobot agar menghindari terjasinya subjektifitas yang tinggi pada nilai bobot. Dan dilakukan perbaikan sistem agar menjadi lebih baik seperti menggabungkan metodemetode lain dan pembuatan aplikasi lebih berbasis desktop atau android..

\section{Daftar Pustaka :}

Figueira, J.,Mousseau, V. dan Roy, B., 2005, "Electre Methods", In J. Figueira, S. Greco, and M. Ehrgott (Eds), Multiple Criteria Decision Analysis: state of the Art Surveys, Chapter 4, Springer Science+Business Media, Inc.,New York. 133-162

Indira. 2012. Seleksi Supplier Bahan Baku Dengan Metode Topsis Fuzzy MADM (Studi Kasus PT.Giri Sekar Kedaton,Gresik).Surabaya: Institut Teknologi Sepuluh November Surabaya.

Kusumadewi, S., dkk. 2006. Fuzzy Multi Attribute Decision Making. Yogyakarta: Graha Ilmu.

Murnawan, F., Akhmad. 2012. Sistem Pendukung Keputusan Menggunakan Metode Technique for Order by Similarity to Ideal Solution (TOPSIS). Bandung: STMIK LKPIA

Prasetyono, Sunar, Dwi. 2012. A-Z Daftar Tanaman Obat Ampuh di Sekitar Kita. Yogyakarta: Flash Books. 707-710

Pressman RS. 2005. Software Engineering, a Practitioner's Approach. Edisi ke-6. McGrawHill.

Trinita, T.S., Sistem Pendukung Keputusan Untuk Pemilihan Tanaman TOGA Dengan Metode ELECTRE (Elimination Et Choix Traduisant La Realite).

Tripathi, K., Decision Support System is a Tool For Making Better Decisions in The Organization. Kolhapur, India. 112-113

Turban, E., 2007,"Decision Support System and Intelligent System", Prentice Hal, New Delhi.

Valensia, Verina, Dewi Lulu W, Yohana, \& Diah Kusuma Wardhani, Kartina. 2012. Aplikasi Sistem Pendukung Keputusan Menggunakan Metode Simple Additive Weighting. Jurnal Teknik Informatika (Vol 1). 1 - 6 